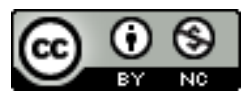

Jurnal Pendidikan Matematika Indonesia is licensed under A Creative Commons Attribution-Non Commercial 4.0 International License.

\title{
PENERAPAN MODEL PEMBELAJARAN BLENDED LEARNING PADA MATA KULIAH LOGIKA DAN PENALARAN MATEMATIKA
}

\author{
Hartono $^{1)}$, Marhadi Saputro ${ }^{2)}$, Dona Fitriawan ${ }^{3)}$ \\ 1) IKIP PGRI Pontianak, Pontianak, Indonesia \\ E-mail:andra.hartono@gmail.com \\ 2) IKIP PGRI Pontianak, Pontianak, Indonesia \\ E-mail: marhadisaputro@ikippgriptk.ac.id \\ 3) Universitas Tanjungpura, Pontianak, Indonesia \\ E-mail: donafitriawan@yahoo.co.id
}

\begin{abstract}
Penelitian ini bertujuan mengetahui hasil penerapan model pembelajaran blended learning pada mata kuliah logika dan penalaran matematika. Secara spesifik tujuan dalam penelitian dibagi dalam sub tujuan yaitu untuk mengetahui:1) Prestasi belajar matematika setelah diterapkan model pembelajaran blended learning pada mata kuliah Logika dan Penalaran Matematika; 2) Besarnya peningkatan prestasi belajar matematika setelah diterapkan model pembelajaran blended learning pada mata kuliah Logika dan Penalaran Matematika. Metode dalam penelitian ini adalah metode eksperimen, sedangkan Bentuk penelitian yang digunakan dalam penelitian ini adalah pre-experimental design dengan rancangan penelitian one group pretest-posttest design. Populasi dalam penelitian ini adalah mahasiswa program studi Pendidikan Matematika IKIP PGRI Pontianak terkhusus yang diampu mata kuliah Logika dan Penalaran Matematika. Sampel dalam penelitian ini adalah mahasiswa kelas A Pagi pada mata kuliah Logika dan Penalaran Matematika. Hasil penelitian diperoleh bahwa penerapan model pembelajaran blended Learning pada materi logika matematika memberikan peningkatan terhadap prestasi belajar mahasiswa. Prestasi belajar mahasiswa sebelum diberikan model pembelajaran blended learning tergolong kurang yaitu 52. Prestasi belajar mahasiswa setelah diberikan model pembelajaran blended learning tergolong baik yaitu 72 . Hasil uji hipotesis juga diperoleh terdapat peningkatan prestasi belajar mahasiswa setelah diberikan model blended learning pada mata kuliah logika dan penalaran matematika dengan peningkatan sebesar 1,132 yang tergolong tinggi.
\end{abstract}

\section{PENDAHULUAN}

Pembelajaran merupakan suatu proses yang terdiri dari kombinasi dua aspek, yaitu: belajar tertuju kepada apa yang harus dilakukan oleh peserta didik, mengajar berorientasi pada apa yang harus dilakukan oleh pendidik sebagai pemberi pelajaran. Kedua aspek ini akan berkolaborasi secara terpadu menjadi suatu kegiatan pada saat terjadi interaksi antara pendidik dengan peserta didik, serta antara para peserta didik di saat pembelajaran sedang berlangsung. Hal tersebut juga berlaku pada mahasiswa dan dosen. Dengan kata lain, pembelajaran pada hakikatnya merupakan proses komunikasi antara peserta didik dengan pendidik serta antar peserta didik dalam rangka perubahan sikap (Suherman dalam Jihad dan Haris, 2013: 11). Karena itu baik konseptual maupun operasional konsep-konsep komunikasi dan perubahan sikap akan selalu melekat pada pembelajaran.

Dalam proses pembelajaran, baik pendidik maupun peserta didik bersama-sama menjadi pelaku terlaksananya tujuan pembelajaran. Tujuan pembelajaran ini akan mencapai hasil yang maksimal apabila pembelajaran berjalan secara efektif. Menurut Wragg (Jihad dan Haris, 2013: 12) pembelajaran yang efektif adalah pembelajaran yang memudahkan peserta didik untuk mempelajari sesuatu yang bermanfaat seperti fakta, keterampilan, nilai, konsep, dan bagaimana hidup serasi dengan sesama, atau suatu hasil belajar yang diinginkan. Dari uraian terlihat bahwa proses pembelajaran bukan sekadar transfer ilmu dari pendidik kepada peserta didik atau dosen kepada mahasiswa, melainkan suatu proses kegiatan, yaitu terjadi interaksi antara pendidik dengan peserta didik serta antara peserta didik dengan peserta didik atau antara pendidik dengan mahasiswa serta antara mahasiswa dengan mahasiswa. Pembelajaran hendaknya tidak menganut paradigma sebagai transfer of knowledge, yang mengandung makna bahwa peserta didik merupakan objek dari belajar. Tapi upaya untuk membelajarkan peserta didik ditandai dengan kegiatan memilih, menetapkan, mengembangkan metode untuk mencapai hasil pembelajaran yang diinginkan. Pemilihan, penetapan, dan pengembangan model pembelajaran ini didasarkan pada kondisi pembelajaran yang ada. Dalam hal ini istilah pembelajaran memiliki hakekat perencanaan atau perancangan (desain) sebagai upaya untuk membelajarkan peserta didik/mahasiswa. Itulah sebabnya dalam belajar, peserta didik/mahasiswa tidak berinteraksi dengan pendidik/dosen sebagai salah satu sumber belajar, tetapi berinteraksi dengan keseluruhan sumber belajar yang mungkin dipakai untuk mencapai tujuan pembelajaran. Oleh 


\section{- - - Jurnal Pendidikan Matematika Indonesia \\ Volum 4 Nomor 2 bulan September 2019. Page 84 - 89 \\ p-ISSN: 2477-5967 e-ISSN: 2477-8443}

karena itu pembelajaran menaruh perhatian pada "bagaimana membelajarkan peserta didik/mahasiswa" dan bukan pada "apa yang dipelajari peserta didik/mahasiswa" (Jihad dan Haris, 2013: 12-13).

Model pembelajaran merupakan suatu cara tertentu yang digunakan untuk membantu peserta didik dalam belajar. Sebagaimana yang diungkapkan Joyce dan Calhourn (2004: 7) bahwa "Model of teaching are really models of learning. As we help student acquire information, ideas, skills, value, ways of thinking and means of expressing themselves, we are also teaching them how to learn". Model pengajaran sebenarnya adalah model belajar. Pendidik membantu peserta didik untuk memperoleh informasi, ide, keterampilan, cara berpikir, dan mengekspresikan ide diri sendiri. Dalam hal ini, bantuan yang dimaksud adalah pendidik memfasilitasi peserta didik agar dapat mengembangakn pikirannya dalam belajar untuk memperoleh pengetahuan yang diperlukan. Istilah model pembelajaran memiliki makna yang lebih luas daripada strategi, metode, atau prosedur. Model pembelajaran meliputi pendekatan yang luas dan menyeluruh.

Menurut Joyce dan Calhourn (2004: 15) model pembelajaran adalah suatu perencanaan yang digunakan sebagai pedoman dalam merencanakan pembelajaran dikelas atau pembelajaran dalam tutorial dan untuk menentukan perangkat-perangkat pembelajaran termasuk didalamnya buku-buku , film, komputer, kurikulum dan sebagainya. Selain itu Bruce (Joyce dan Calhourn, 2004: 18) menyatakan setiap model mengarahkan dalam mendesain pembelajaran membantu peserta didik sedemikian sehingga tujuan pembelajaran tercapai.

Joyce dan Calhourn (2004: 20) mengemukakan ada lima unsur penting dari suatu model pembelajaran yaitu: (1) sintaks, yakni suatu urutan atau fase kegiatan atau langkahlangkah pembelajaran, (2) sistem sosial, yakni menguraikan peranan pendidik dan peserta didik, serta aturan-aturan yang diperlukan dalam interaksi sosial-kultural. (3) prinsip-prinsip reaksi, yakni memberi gambaran kepada pendidik tentang cara memandang atau merspon pertanyaan-pertanyaan peserta didik, (4) sistem pendukung, yakni kondisi yang diperlukan agar model dapat terlaksana secara efektif dan efisien, dan (5) dampak instruksional dan pengiring. Dampak pembelajaran adalah hasil belajar yang dicapai langsung dengan cara mengarahkan para peserta didik pada tujuan yang diharapkan. Sedangkan dampak pengiring adalah hasil belajar lainnya yang dihasilkan oleh suatu proses pembelajaran sebagai akibat terciptanya suasana belajar yang dialami sendiri oleh peserta didik tanpa arahan langsung dari pendidik.

Model pembelajaran blended learning menawarkan kombinasi antara model pembelajaran tatap muka (face to face) dengan model pembelajaran berbasis e-learning. Model pembelajaran ini memfasilitasi peserta didik selama proses pembelajaran. Dengan menerapkan model blended learning maka akan terjadi perubahan dimana proses pembelajaran tidak hanya mendengarkan uraian dari pendidik tetapi peserta didik dapat menggunakan fasilitas e-learning yang dapat diakses kapan saja dan di mana saja. Dengan diterapkannya model ini diharapkan dapat membuat peserta didik lebih tertarik untuk mengikuti kegiatan belajar di dalam maupun di luar ruangan.

Blended learning merupakan model pembelajaran yang berasal dari pertimbangan-pertimbangan dalam menyempurnakan sistem belajar e-learning. Dari studi yang ada, kendala terbesar e-learning adalah proses interaksi langsung antara pendidik dengan peserta didik. Bagaimanapun belajar merupakan proses dua arah. Peserta didik memerlukan feedback dari pendidik dan sebaliknya pendidik juga memerlukan feedback dari peserta didiknya. Dengan cara ini akan didapat hasil belajar yang lebih efektif dan tepat sasaran. Hal ini menjawab mengapa program e-learning tidak selalu mendapat hasil memuaskan. Seringkali materi sudah banyak dan tersedia dengan lengkap. Orang juga bisa belajar kapan saja dan di mana saja, asal terkoneksi lewat jaringan nirkabel. Namun tetap saja tingkat penggunaan materi-materi $e$ learning tersebut tergolong rendah. Secara sederhana dapat dikatakan seseorang butuh teman dan butuh feedback langsung. Sama seperti yang dirasakan dalam pembelajaran konvensional di ruang kelas.

Menurut Harding (Jared, M.C, 2015: 137), blended learning merupakan pendekatan pembelajaran yang mengintegrasikan pembelajaran tradisonal tatap muka dan pembelajaran jarak jauh yang menggunakan sumber belajar online dan beragam pilihan komunikasi yang dapat digunakan oleh pendidik dan siswa. Pelaksanaan pendekatan ini memungkinkan penggunaan sumber belajar online dengan tanpa meninggalkan kegiatan tatap muka.

Menurut Jared M.C, (2015: 140), seorang President Aglint Learning menyebutkan lima kunci dalam mengembangkan blended learning. Adapun kelima kunci tersebut yaitu: a) Live Event, Pembelajaran langsung atau tatap muka (instructor-led instruction) secara sinkronous dalam waktu dan tempat yang sama (classroom) ataupun waktu sama tapi tempat berbeda (seperti virtual classroom). Bagi beberapa orang tertentu, pola pembelajaran langsung seperti ini masih menjadi pola utama. Namun demikian, pola pembelajaran langsung inipun perlu didesain sedemikian rupa untuk mencapai tujuan sesuai kebutuhan; b) Self-Paced Learning, Mengkombinasikan pembelajaran konvensional dengan pembelajaran mandiri (self-paced learning) yang memungkinkan peserta belajar kapan saja, di mana saja dengan menggunakan berbagai konten (bahan belajar) yang dirancang khusus untuk belajar mandiri baik yang bersifat text-based maupun multimedia-based (video, animasi, simulasi, gambar, audio, atau kombinasi dari kesemuanya). Bahan belajar tersebut, dalam konteks saat ini dapat dikirim secara online (via web maupun via mobile device dalam bentuk: streaming audio, streaming video, e-book) maupun offline (dalam bentuk $\mathrm{CD}$, cetak, dan lain lain); c) Collaboration, Mengkombinasikan kolaborasi, baik kolaborasi pengajar, maupun kolaborasi antarpeserta belajar yang kedua-duanya bisa lintas sekolah. Dengan demikian, perancang blended learning harus meramu bentuk-bentuk kolaborasi, baik kolaborasi antarpeserta belajar atau kolaborasi antara peserta belajar dan pengajar melalui komunikasi yang memungkinkan seperti chatroom, forum diskusi, email, website/webblog, mobile phone. Tentu saja 
kolaborasi diarahkan untuk terjadinya konstruksi pengetahuan dan keterampilan melalui proses sosial atau interaksi sosial dengan orang lain, bisa untuk pendalaman materi, problem solving, project based learning, dan lain-lain; d) Assessment, Tentu saja, dalam proses pembelajaran jangan lupakan cara untuk mengukur keberhasilan belajar (teknik asesmen). Dalam blended learning, perancang harus mampu meramu kombinasi jenis asesmen baik yang bersifat tes maupun non-tes, atau tes yang lebih bersifat otentik (authentic assessment/ portofolio) dalam bentuk project, produk dan lain-lain. Disamping itu, juga perlu mempertimbangkan antara bentuk-bentuk assessment online dan assessment offline. Sehingga memberikan kemudahan dan fleksibilitas peserta belajar mengikuti atau melakukan asesmen tersebut; e) Performance Support Materials, Ini bagian yang juga jangan sampai terlupakan. Jika ingin mengkombinasikan antara pembelajaran tatap muka dalam kelas dan tatap muka virtual, pastikan sumber daya untuk mendukung hal tersebut siap atau tidak, ada atau tidak. Bahan belajar disiapkan dalam bentuk digital, apakah bahan belajar tersebut dapat diakses oleh peserta belajar baik secara offline maupun secara online.

Model pembelajaran ini sangat cocok digunakan pada materi yang berbasis e-learning sehingga materi logika dan penalaran matematika sangat tepat untuk digunakan. Mata kuliah ini sangat mementingkan pada contoh-contoh di dunia maya sehingga akan menimbulkan ketertarikan belajar yang tinggi bagi mahasiswa. Lalu dilengkapi dengan pembelajaran konvensional dan diskusi teman sejawat, sangat diharapkan materi ini akan semakin mudah untuk dipahami.

Berdasarkan fakta yang diuraikan pada latar belakang, peneliti berkeinginan untuk menerapkan model pembelajaran blended learning pada mata kuliah Logika dan Penalaran Matematika. Penelitian ini diharapkan menghasilkan salah satu model pembelajaran yang sesuai digunakan pada mahasiswa Program Studi Pendidikan Matematika IKIP PGRI Pontianak. tujuan penelitian ini adalah untuk mengetahui hasil dari penerapan model pembelajaran blended learning pada mata kuliah logika dan penalaran matematika. Lebih khusus penelitian ini bertujuan untuk mengetahui Prestasi belajar matematika setelah diterapkan model pembelajaran blended learning pada mata kuliah Logika dan Penalaran Matematika dan besarnya peningkatan prestasi belajar matematika setelah diterapkan model pembelajaran blended learning pada mata kuliah Logika dan Penalaran Matematika.

\section{METODE}

Metode dalam penelitian ini adalah metode eksperimen. Zuldafrial (2011: 177) menyatakan dua alasan mengapa metode eksperimen cocok dilakukan dan sesuai dengan penelitian ini. 1) metode pengajaran ini di setting secara alami dan dikomparasikan di dalam keadaan yang tidak biasa, 2) penelitian dasar dengan tujuan menurunkan prinsipprinsip umum teoretis ke dalam ilmu terapan sesuai dengan permasalahan yang dihadapi.

Menurut Sugiyono (2010: 73) menyatakan bahwa ada empat penelitian yang digunakan berdasarkan metode ekperimennya yaitu: (1) pre-experimental design; (2) true experimental design; (3) factorial design; (4) quasi experimental design. Bentuk penelitian yang digunakan dalam penelitian ini adalah pre-experimental design dengan rancangan penelitian one group pretest-posttest design.

Populasi dalam penelitian ini adalah mahasiswa program studi Pendidikan Matematika IKIP PGRI Pontianak terkhusus yang diampu mata kuliah Logika dan Penalaran Matematika. Sampel dalam penelitian ini adalah mahasiswa kelas A Pagi pada mata kuliah Logika dan Penalaran Matematika. Teknik pengumpul data dalam penelitian ini adalah teknik pengukuran dengan alatnya berupa tes soal Logika dan Penalaran Matematika. Nantinya juga disertai teknik dokumentasi dengan mengumpulkan dokumendokumen yang diperlukan.

Teknik analisis data, untuk memperoleh data tujuan penelitian tentang peningkatan prestasi belajar matematika setelah diterapkan model pembelajaran blended learning pada mata kuliah Logika dan Penalaran Matematis dilakukan uji hipotesis dengan uji prasyarat analisis melalui: 1) Uji normalitas dengan rumus liliefors; 2) Uji homogenitas dengan uji F. Uji analisis dengan menggunakan uji-t sesuai ketentuan (Jika ada kejadian tidak normal atau tidak homogen). Untuk mengetahui seberapa besar peningkatan ketika diterapkan model pembelajaran blended learning pada mata kuliah Logika dan Penalaran Matematis digunakan statistik uji mannwhitney. (Budiyono, 2009: 57).

\section{HASIL DAN PEMBAHASAN}

Penelitian dilaksanakan pada sampel yang telah ditentukan, yaitu mahasiswa Program Studi Pendidikan Matematika semester 2 tahun akademik 2017/2018 yang dilakukan pada bulan April - Juni 2018 dengan jumlah sampel sebanyak 31 mahasiswa. Penelitian dilakukan berupa pemberian materi pendahuluan, konsep dasar logika matematika yaitu pernyataan atau proposisi, notasi atau nilai kebenaran. Setelah diberikan materi pengantar tersebut, mahasiswa diberikan pretes mengenai materi yang telah disampaikan. Prestasi belajar mahasiswa disajikan ke dalam Tabel 1.

TABEL 1

PRESTASI BELAJAR MAHASISWA MK LOGIKA MATEMATIKA DAN PENALARAN

\begin{tabular}{llcccc}
\hline No & Kode & \multicolumn{2}{c}{ Pretest } & \multicolumn{2}{c}{ Posttest } \\
\cline { 3 - 6 } & Siswa & Nilai & Kategori & Nilai & Kategori \\
$\mathbf{1}$ & TJ & 32 & Gagal & 63,90 & Cukup \\
$\mathbf{2}$ & KW & 80 & Amat Baik & 85,75 & Amat Baik \\
$\mathbf{3}$ & AP & 25 & Gagal & 61,00 & Cukup \\
$\mathbf{4}$ & FB & 57 & Kurang & 73,90 & Baik \\
$\mathbf{5}$ & ANB & 35 & Gagal & 71,25 & Baik \\
$\mathbf{6}$ & LO & 30 & Gagal & 63,75 & Cukup \\
$\mathbf{7}$ & AR & 50 & Kurang & 66,50 & Cukup \\
$\mathbf{8}$ & HV & 40 & Gagal & 68,90 & Cukup \\
\hline
\end{tabular}




\begin{tabular}{|c|c|c|c|c|c|}
\hline 9 & KM & 80 & Amat Baik & 85,50 & Amat Baik \\
\hline 10 & $\mathrm{RN}$ & 65 & Cukup & 79,75 & Baik \\
\hline 11 & YA & 50 & Kurang & 68,00 & Cukup \\
\hline 12 & MZM & 30 & Gagal & 62,75 & Cukup \\
\hline 13 & DP & 65 & Cukup & 76,65 & Baik \\
\hline 14 & SDP & 60 & Cukup & 73,00 & Baik \\
\hline 15 & YA & 40 & Gagal & 69,75 & Cukup \\
\hline 16 & EMA & 25 & Gagal & 51,40 & Kurang \\
\hline 17 & RIKA & 75 & Baik & 71,60 & Baik \\
\hline 18 & YULIA & 60 & Cukup & 82,35 & Amat Baik \\
\hline 19 & ADC & 60 & Cukup & 83,25 & Amat Baik \\
\hline 20 & $\mathrm{AE}$ & 43 & Gagal & 65,35 & Cukup \\
\hline 21 & GY & 30 & Gagal & 60,75 & Cukup \\
\hline 22 & SAR & 68 & Cukup & 72,60 & Baik \\
\hline 23 & $\mathrm{RY}$ & 45 & Gagal & 75,65 & Baik \\
\hline 24 & EDT & 47 & Gagal & 77,50 & Baik \\
\hline 25 & AAM & 70 & Baik & 78,75 & Baik \\
\hline 26 & VS & 72 & Baik & 84,90 & Amat Baik \\
\hline 27 & LIOBA & 70 & Baik & 82,50 & Amat Baik \\
\hline 28 & LS & 45 & Gagal & 72,00 & Baik \\
\hline 29 & HMN & 80 & Amat baik & 77,50 & Baik \\
\hline 30 & YYS & 45 & Gagal & 78,75 & Baik \\
\hline 31 & $\mathrm{DC}$ & 30 & Gagal & 58,00 & Kurang \\
\hline \multicolumn{2}{|c|}{ Jumlah } & 1604 & & 2243 & \\
\hline \multicolumn{2}{|c|}{ Rata-rata } & 52 & Kurang & 72 & Baik \\
\hline \multicolumn{2}{|c|}{$\begin{array}{l}\text { Standar } \\
\text { Deviasi }\end{array}$} & 17,67 & & 8,798 & \\
\hline
\end{tabular}

Prestasi belajar mahasiswa pembelajaran materi pengantar logika matematika tanpa blended learning diukur dengan interval keberhasilan belajar dengan diberikan pretest diperoleh 15 orang mahasiswa terkategori gagal, artinya sebanyak 50\% dari jumlah sampel tidak berhasil. Ditambah lagi dengan rata-rata hasil belajar sebesar 52 terkategori kurang, menujukkan secara umum prestasi mahasiswa terpusat kategori kurang. Akan tetapi standar deviasi dari nilai pretest mahasiswa sebesar 17,67 yang dapat dikatakan perbedaan antra data masih cukup besar sehingga dapat disimpulkan bahwa mahasiswa yang satu dengan lainnya memiliki perbedaan cukup besar dalam menyerap materi. Kemudian, setelah diberikan pembelajaran materi lanjutannya dengan blended learning, mahasiswa yang gagal sudah tidak ada lagi, hanya ada dua orang yang nilainya kurang. Untuk rata-rata nilai juga mengalami peningkatan yaitu 72 yang dapat dikatakan prestasi mahasiswa berada pada sekitar kategori baik. Hal tersebut didukung dengan nilai standar deviasi sebesar 8, 798 yang dapat diartikan nilai antar mahasiswa selisihnya tidak sampai 10 di sekitar nilai rata-rata.

Oleh karena itu, secara deskriptif prestasi belajar mahasiswa mengalami peningkatan setelah diterapkan pembelajaran blended learning. Peningkatan terjadi pada jumlah mahasiswa yang mengalami keberhasilan belajar, ratarata hasil belajar, kategori yang diperoleh masing-masing mahasiswa. Selain itu, prestasi mahasiswa cenderung merata peningkatannya terlihat dari nilai standar deviasi yang kecil.

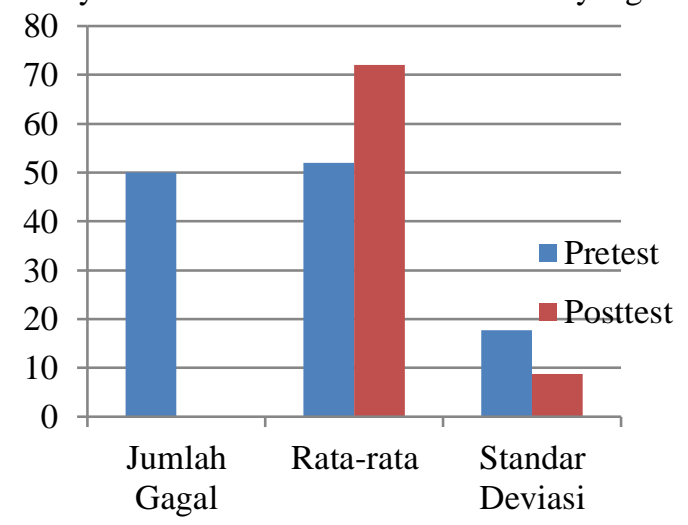

GAMBAR 1.

GRAFIK PENURUNAN DAN PENINGKATAN

Selanjutnya dilakukan pengolahan data secara statistik dengan langkah-langkah yaitu 1) Uji normalitas data nilai pretest (menggunakan uji Lilliefors), Jika $\mathrm{L}_{\mathrm{obs}} \leq \mathrm{L}_{\text {tabel }}$ maka data berdistribusi normal, namun jika $\mathrm{L}$ obs $\geq \mathrm{L}$ tabel maka data tidak berdistribusi normal. Berdasarkan hasil uji normalitas posttest diperoleh nilai $\mathrm{L}_{\mathrm{obs}}<\mathrm{L}_{\text {tabel }}(0,1586<$ 0,1933) maka dapat disimpulkan bahwa data berdistribusi normal. Uji normalitas data nilai Posttest (menggunakan uji Lilliefors). Jika $\mathrm{L}_{\mathrm{obs}} \leq \mathrm{L}_{\text {tabel }}$ maka data berdistribusi normal, namun jika $\mathrm{L}_{\text {obs }} \geq \mathrm{L}$ tabel maka data tidak berdistribusi normal. Berdasarkan hasil uji normalitas posttest diperoleh nilai $\mathrm{L}_{\mathrm{obs}}<\mathrm{L}_{\text {tabel }}(0,1606<0,1933)$ maka dapat disimpulkan bahwa data berdistribusi normal.

Uji Homogenitas menggunakan uji F, Karena data dalam penelitian adalah sebanyak 2 kelompok data yaitu data nilai prettest dan posttest, maka untuk menguji kesamaan ratarata varian-variannya digunakan uji $\mathrm{F}$. Jika $F_{\text {hitung }} \leq \mathrm{F}_{\text {tabel }}$, maka data homogen, namun jika $F_{\text {hitung }} \geq F_{\text {tabel, maka data }}$ tidak homogen. Berdasarkan perhitungan menggunakan uji $\mathrm{F}$ diperoleh nilai $F_{\text {hitung }}<F_{\text {tabel }}$ atau $1,0864<2,1242$ maka dapat dinyatakan bahwa data homogen.

Uji Perbedaan Hasil Post-Test, dari uji normalitas data menggunakan uji Lilliefors dan uji homogenitas menggunakan uji $\mathrm{F}$ diketahui bahwa kedua data berdistribusi normal dan variansnya homogen maka data tersebut dianalisis dengan menggunakan uji $t$ dua pihak dengan langkah-langkah sebagai berikut: 


\section{- - - Jurnal Pendidikan Matematika Indonesia \\ Volum 4 Nomor 2 bulan September 2019. Page 84 - 89 \\ p-ISSN: 2477-5967 e-ISSN: 2477-8443}

1) Rumusan hipotesis

$\mathrm{H}_{0}=$ Tidak terdapat peningkatan prestasi belajar matematika setelah diterapkan model pembelajaran blended learning pada mata kuliah Logika dan Penalaran Matematika.

$\mathrm{H}_{1}=$ Terdapat peningkatan prestasi belajar matematika setelah diterapkan model pembelajaran blended learning pada mata kuliah Logika dan Penalaran Matematika.

2) Menentukan nilai $t_{\text {hitung Nilai }} t_{\text {hitung }}$ yang didapat sebesar 6,661 .

3) Menentukan derajat kebebasan

$\mathrm{db}=n_{1}+n_{2}-2=31+31-2=60$

4) Menentukan $t_{\text {tabel }}$

$t_{\text {tabel }}=\mathrm{t}_{(1-1 / 2} \alpha_{\text {).(db) }}$ dengan taraf signifikansi $\alpha=0,05$

dan $\mathrm{db}=60$, dan diperoleh $t_{\text {tabel }}=2,021$.

5) Menentukan kesimpulan/Hipotesis

Karena jika dalam keadaan $-t_{\text {tabel }} \leq t_{\text {hitung }} \leq+t_{\text {tabel }}$, maka Ho diterima namun pada keadaan berbeda yakni 6,661> 2,021 atau $t_{\text {hitung }} \geq+t_{\text {tabel }}$ yakni 6,661 > 2,021 maka $\mathrm{H}_{\mathrm{o}}$ ditolak pada taraf signifikasi $5 \%$ dan ini berarti bahwa $\mathrm{H}_{1}$ diterima dan $\mathrm{H}_{0}$ ditolak. Jadi kesimpulannya yaitu terdapat peningkatan prestasi belajar matematika setelah diterapkan model pembelajaran blended learning pada mata kuliah Logika dan Penalaran Matematika.

Hasil uji $t$ diketahui bahwa terdapat peningkatan yang signifikan antara rata-rata hasil belajar siswa sebelum dan sesudah diberikan pembelajaran remediasi menggunakan Program Flash dalam menyelesaikan operasi hitung bilangan bulat. Selanjutnya hasil perhitungan nilai Effect Size yaitu:

Diketahui bahwa $\bar{x}_{1}=52$ dan $\bar{x}_{2}=72$ serta $S d \bar{x}_{1}=17,67$

$$
E S=\frac{\bar{x}_{2}-\overline{x_{1}}}{S d_{\overline{x_{1}}}}=\frac{72-52}{17,67}=1,132
$$

Berdasarkan kriteria Effect Size, ES > 0,8 atau 1,132>0,8 tergolong kategori tinggi.

Pelaksanaan penelitian yang dilaksanakan di Program Studi Pendidikan Matematika IKIP PGRI Pontianak secara umum berjalan dengan baik, dimulai dari peneliti melakukan studi lapangan dimana menemukan permasalahan yang perlu untuk dikaji, hingga memberikan materi pengantar kemudian pretest dan dilanjutkan perlakuan serta sampai pada tahap pemberian tes akhir (post-test). Dalam proses pelaksanaan pembelajaran yang dilakukan oleh peneliti semua mahasiswa hadir.

Rata-rata prestasi belajar mahasiswa hasil pretest, tes sebelum pemberian pembelajaran blended learning tergolong kurang, hal ini disebabkan karena selama proses pembelajaran berlangsung mahasiswa terlihat kurang semangat, dan hal ini berpengaruh terhadap prestasi belajar mahasiswa. Selain itu bagi mahasiswa pembelajaran searah membuat pembelajaran menjadi sedikit pasif, berbeda dengan pembelajaran blended learning dapat lebih mudah dalam pembelajaran disebabkan penggunaan model pembelajaran blended learning yang melibatkan semua media yang ada, baik berupa media yang bersifat tata muka maupun yang bersifat jarak jauh online, karena model pembelajaran blended learning memberikan kesempatan kepada mahasiswa mengajukan pertanyaan yang dapat dieperoleh dimana saja asal sesuai dengan konteks pembelajaran yaitu logika matematika.

Pembelajaran yang berlangsung pada pertemuan pertama sebelum diberikan blended learning berupa materi pengantar logika yaitu definisi dari logika dan proposisi. Pada pertemuan kedua mahasiswa diberikan materi lanjutannya yaitu perangkat dasar logika dan pada pertemuan yang ketiga mahasiswa diberikan pre-test untuk mengetahui prestasi belajar mahasiswa yang telah diberikan pembelajaran langsung sebagai tes sebelum pembelajaran blended learning.

Berdasarkan dari hasil pengolahan data, diperoleh beberapa hasil dari penelitian yakni hasil penelitian yang pertama bahwa rata-rata prestasi belajar mahasiswa pada pretest tergolong kurang, hal ini disebabkan karena pemberian materi logika matematika sebelum diberikan pembelajaran menggunakan model pembelajaran blended learning yang membuat siswa menjadi lebih aktif untuk melakukan kegiatan belajar, berdiskusi, saling bertanya dan memahami materi yang disampaikan. Hal tersebut didukung hasil penelitian Sjukur (2012: 374) yang menyatakan blended learning meningkatkan motivasi belajar. Adapun Pembelajaran dengan model pembelajaran blended learning dilaksanakan selama empat kali pertemuan.

Secara umum proses pembelajaran berjalan lancar. Pada pertemuan pertama, mahasiswa pada kelas logika dan penalaran matematika diberikan perlakuan dengan model pembelajaran blended learning yang telah dirancang dalam rencana perkuliahan semester (RPKPS), pembelajaran dilakukan selama dua SKS yang mana satu SKS berdurasi 50 menit. Pembelajaran dimulai dengan kegiatan awal yang memuat motivasi dan tujuan pembelajaran serta apersepsi mengenai kalimat matematika. Pendahuluan pembelajaran diperlukan untuk mengkondisikan mood mahasiswa dalam belajar sesuai dengan hasil penelitian Sumartini (2017: 1). Pada pertemuan kedua, mahasiswa kelas logika dan penalaran matematika tetap diberikan pembelajaran menggunakan model pembelajaran blended learning. Dan saat materi sudah selesai, mahasiswa diberikan post-test untuk mengetahui prestasi belajar mahasiswa yang telah diberikan pembelajaran menggunakan model pembelajaran blended learning Mahasiswa yang memperoleh nilai dengan kategori baik meningkat secara kuantitas, dan kualitas pembelajaran memberikan karakter kemandirian bagi mahasiswa karena mereka harus mencari sendiri permasalahan dalam blended learning ini. Kemadirian belajar dalam blended learning ini juga diteliti oleh Fitriasari, dkk (2018:1) yang diperoleh kemandirian belajarnya lebih baik dari pembelajaran biasa.

Uji hipotesis (Ha) dengan menggunakan uji t (karena kedua data berdistribusi normal dan homogen) diperoleh $t_{\text {hitung }} \geq+t_{\text {tabel }}$, atau 6,661 $<2,021$ yang jatuh pada daerah penolakan $\mathrm{Ho}$ yang berarti bahwa $\mathrm{H}_{1}$ diterima. Berdasarkan hipotesis, Jadi kesimpulannya yaitu terdapat peningkatan prestasi belajar matematika secara signifikan setelah diterapkan model pembelajaran blended learning pada mata 
kuliah Logika dan Penalaran Matematika. Menurut Suparno (Rezeki, 2014: 17), prinsip-prinsip konstuktivisme yang banyak digunakan dalam pendidikan adalah pengetahuan dibangun oleh siswa secara aktif, tekanan dalam proses belajar terletak pada siswa, mengajar adalah membantu siswa belajar, tekanan dalam proses belajar lebih pada proses bukan pada hasil akhir, kurikulum menekankan partisipasi siswa dan guru sebagai fasilitator.

Berdasarkan hasil penelitian serta mengacu pada prinsipprinsip konstruktivisme yang diuraikan di atas, maka model pembelajaran blended learning cocok dalam kegiatan pembelajaran, karena pembelajaran matematika memfokuskan pada proses berfikir mahasiswa, bukan sekedar kepada hasil. Selain itu, dalam pembelajaran ini mengutamakan peran siswa berinisiatif dan berkomunikasi untuk menemukan jawaban dari permasalahan kontekstual yang diberikan oleh pengajar melalui cara mahasiswa sendiri dan mahasiswa didorong aktif dalam kegiatan pembelajaran. Hal itu menunjukkan pembelajaran dilakukan oleh mahasiswa melalui berbagai macam sumber dan aktifitas pembelajaran sehingga Prayitno (2015: 1) mengatakan pembelajaran blended learning sebagai pembelajaran yang semestinya dilakukan. Blended learning yang menuntut aktifitas belajar mengakibatkan terjadinya peningkatan prestasi belajar mahasiswa pada mata kuliah logika matematika dan penalaran seperti halnya penelitian Muchtadi dkk (2017: 1) terdapat hubungan antara aktifitas dan hasil belajar mahasiswa dimana aktifitas belajar mahasiswa yang baik diikuti hasil belajar yang baik.

\section{KESIMPULAN}

Hasil analisis data secara umum penelitian penerapan model pembelajaran blended Learning pada materi logika matematika memberikan peningkatan terhadap prestasi belajar mahasiswa dapat disimpulkan bahwa prestasi belajar mahasiswa sebelum diberikan model pembelajaran blended learning tergolong kurang yaitu 52. Prestasi belajar mahasiswa setelah diberikan model pembelajaran blended learning tergolong baik yaitu 72 . Hasil uji hipotesis juga diperoleh terdapat peningkatan prestasi belajar mahasiswa setelah diberikan model blended learning pada mata kuliah logika dan penalaran matematika dan peningkatan prestasi belajar mahasiswa setelah diberikan model blended learning pada materi logika dan penalaran matematika sebesar 1,132 yang tergolong tinggi.

\section{UCAPAN TERIMA KASIH}

Kami penulis mengucapkan terima kasih kepada IKIP PGRI Pontianak atas dukungan dana yang diberikan dalam penelitian ini dan Program Studi Pendidikan Matematika yang telah memberikan ijin pelaksanaan penelitian ini serta Tim Pengelola Jurnal Pendidikan Matematika Indonesia STKIP Singkawang.

\section{REFERENSI}

Budiyono. 2009. Statistik untuk Penelitian. Surakarta: UNS Press.
Brodie, K. 2010. Teaching Mathematical Reasoning in Secondary School Clasroom. New York: Springer.

Fitriasari, Putri. Tanzimah \& Sari, Novita. 2018. Kemandirian Belajar Mahasiswa melalui Blended Learning pada Mata Kuliah Metode Numerik. Jurnal Elemen Vol 4 Nomor 1. Diakses di pada tanggal 05 November 2018

Jared, M. C. 2015. Blended Learning Design. Five Key Ingredients.

Jihad, A., \& Haris, A. 2013. Evaluasi Pembelajaran. Yogyakarta: Multi Pressindo.

Joice, B. W., \& Calhoun, E. 2004. Model of Teaching. Boston Allyn and Bacon.

Muchtadi. Hartono. \& Oktaviana, D. 2017. Hubungan Aktivitas dan Respon terhadap Hasil Belajar Program Linier setelah Diterapkan Pembelajaran Genius Learning pada Program Studi Pendidikan Matematika. Jurnal Pendidika Sains dan Matematika Edusains Vol 05 No 01. Palangkaraya: IAIN Palangkaraya diakses di http://e-journal.iain-

palangkaraya.ac.id/index.php/edusains/article/downloa d/668/719 tanggal 18 Desember 2018

Prayitno, W. 2015. Penerapan Blended Learning dalam Pengembangan Pendidikan dan Pelatihan (DIKLAT) bagi Pendidik dan Tenaga Kependidikan (PTK). Yogyakarta: LPM Yogyakarta.

Sumartini, T.S. 2017. Pembelajaran Mood, Understand, Recall, Detect, Elaborate, and Review (Murder) Berbasis Proyek Dalam Pembelajaran Matematika. Jurnal Mosharafa Vol 6 No 3. Diakses di https://media.neliti.com/media/publications/226573pembelajaran-mood-understand-recall-dete71c4ecb7.pdf 18 Desember 2018

Sugiyono. 2010. Metode Penelitian Kuantitatif, Kualitatif, dan $R \& D$. Bandung: Alfabeta.

Sutrisno, Leo. 1991. Tes Diagnostik dan Remediasi Pendidikan Matematika. Pontianak: FKIP Untan

Sjukur, SulihinB. 2012. Pengaruh Blended Learning Terhadap Motivasi Belajar dan Hasil Belajar Siswa Tingkat SMK. Jurnal Pendidikan Vokasi Vol 2 No 3. Yogyakarta: Universitas Negeri Yogyakarta

Zuldafrial. 2011. Penelitian Kuantitatif. Pontianak: IAIN Press. 